\title{
Analysis of climate variability and droughts in East Africa using high-resolution climate data products
}

(i) The corrections made in this section will be reviewed and approved by journal production editor.

Solomon H. Gebrechorkos ${ }^{\mathrm{a}, \mathrm{b}, *}$ gebrechorkos@unu.edu, Stephan Hülsmann ${ }^{\mathrm{a}, \mathrm{c}}$, Christian Bernhofer ${ }^{\mathrm{d}}$

${ }^{a}$ United Nations University Institute for Integrated Management of Material Fluxes and of Resources (UNU-FLORES), 01067 Dresden, Germany

${ }^{\mathbf{b}}$ School of Geography and Environmental Science University of Southampton, SO17 1BJ Southampton, United Kingdom

'Global Change Research Institute CAS, 60300 Brno, Czech Republic

${ }^{d}$ Faculty of Environmental Sciences, Institute of Hydrology and Meteorology, Technische Universität Dresden, 01062 Dresden, Germany

*Corresponding author at: United Nations University Institute for Integrated Management of Material Fluxes and of Resources (UNU-FLORES), 01067 Dresden, Germany.

\begin{abstract}
Analysis of climate variability and change as a basis for adaptation and mitigation strategies requires long-term observations. However, the limited availability of ground station data constrains studies focusing on detecting variability and changes in climate and drought monitoring, particularly in developing countries of East Africa. Here, we use high-resolution precipitation (1981-_2016) and maximum and minimum temperature (T-max and T-min) (1979-_2012) datasets from international databases like the Climate Hazard Group (CHG), representing the most accurate data sources for the region. We assessed seasonal, annual, and decadal variability in rainfall, T-max and T-min and drought conditions using the StandardisedStandardized Precipitation Index (SPI). The impact of changes in Sea Surface Temperature on rainfall variability and droughts is assessed using the Nino3.4 and Indian Ocean Dipole (IOD) indices. The results show maximum variability in rainfall during October-_December (OND, short rainy season) followed by March-_May (MAM, long rainy season). Rainfall variability during OND showed a significant correlation with IOD in Ethiopia (69\%), Kenya (80\%), and Tanzania (63\%). In Ethiopia, the period June--September
\end{abstract}


(JJAS) showed a significant negative correlation (-- 56\%) with the Nino3.4. Based on the 12-month SPI, the eastern and western parts of the region are getting drier and wetter, respectively with an average of mild, moderate, and severe droughts of more than $37 \%, 6 \%$, and $2 \%$ of the study period, respectively. The observed severe droughts (e.g., 1999/2000) and extreme floods (e.g., 1997/1998) were found to be linked to respective negative and positive anomalies of the Nino3.4. In general, climate data products with high spatial resolution and accuracy help detect changes and variability in climate at local scale where adaptation is required.

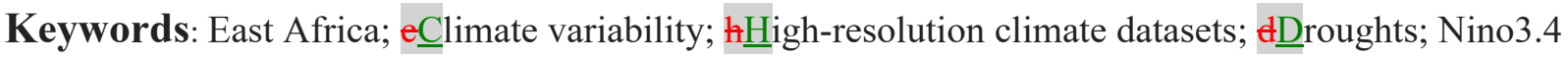

\subsection{Introduction}

Countries in East Africa are particularly prone to climate variability (e.g., inter-annual variability in rainfall) and extreme climate events such as droughts and floods (WWF, 2006; Niang et al., 2014). The region is facing an increasing trend in maximum and minimum temperature and temperature extremes (e.g., increase in high and low percentiles of the temperature distribution) and high variability in seasonal rainfall and daily rainfall extremes (e.g., monthly maximum 1-day and 5-day precipitation) (Cattani et al., 2018; Gebrechorkos et al., 2018a). Due to the high variability in seasonal rainfall and occurrence of extreme events, the region is becoming one of the most food-insecure regions in the world looking for humanitarian assistance (ActionAid, 2016; Sidahmed, 2018). Moreover, as a result of high variability in rainfall, poor management of environmental resource, and absence of improved technologies, agricultural production is very low in SubSaharan Africa (IFPRI, 2009). Agriculture is the dominant sector in Africa and more than 80\% of the population in East Africa depends on it, which also provides a significant contribution (up to 40\%) to the economy of the region (FAO, 2014). In addition to agriculture, sectors such as water and energy and environmental resources (e.g., land) are increasingly affected by the changes and variability in climate (Niang et al., 2014). Agriculture in East Africa is largely rain-fed and it is based on the long (March--May) and short (October-_December) rainy seasons, which makes the agriculture sector highly vulnerable to inter-annual rainfall variability. The change and shift in rainfall during March--May and October--December rainy seasons, which are the main cropping periods in the region, led to devastating droughts affecting the socioeconomic welfare and environment (Haile et al., 2019). In East Africa, droughts are becoming a recurring event, every three years science 2005, and it has been difficult to manage the impacts due to limited forecasting skills and other anthropogenic and natural factors (Haile et al., 2019).

In addition to seasonal rainfall variability, one of the main challenges that make the region highly vulnerable to droughts and climate variability lies in the fact that the major portion of the agricultural land is owned by smallholder farmers. The land owned by the smallholder farmers provides about $90 \%$ of the total agricultural production (Salami et al., 2010) and they have less knowledge and capacity to adapt to any change in weather and climate, adding to the vulnerability of the agricultural sector (Kotir, 2011). Climate projections, in line to the observed change, show an increase in maximum and minimum temperature (Gebrechorkos et al., 2019a) and frequency of extreme events (e.g., droughts, floods, and heavy rainstorms) in East Africa (IPCC, 2007; Niang et al., 2014), which will pose a negative impact on the environment and the region'-'s economy, health 
and wellbeing. According to IPCC (2007), by the end of 2100, the region's economy is projected to decline by $2 \%-7 \%$ as the result of the impact of climate change and variability on agriculture. Compared to the change in temperature, the change and variability in rainfall induce a significant impact on agriculture. In general, considering the vulnerability of the region to climate change and variability and the projected change in climate (increase in temperature and variability in precipitation), development of adaptation measures to reduce the possible impacts is urgently needed. In this region, there is already a growing interest in understanding the climate condition e.g., identifying the possible drivers of seasonal variability in rainfall at different spatial scales (watershed to regional scale) based on different datasets such as remote sensing-based rainfall products and climate model output (Wolff et al., 2011; Endris et al., 2013; Endris et al., 2015; Fer et al., 2017; Mpelasoka et al., 2018).

While most of the studies in this region focus on identifying the drivers, the number of studies dealing with the spatial and temporal variability providing high-resolution maps to identify hot spot areas which should be prioritized in adaptation plans are limited (e.g., Daron, 2014; Rowell et al., 2015; Seregina et al., 2014; Tierney et al., 2013). In addition, most of the earlier studies are confined to watersheds scale based on limited information from field-based meteorological stations and relay on regional averages based on coarse resolution of climate data such as output from Global Climate Models (GCMs). However, due to the limited, in terms of spatial and temporal coverage, availability of ground station data large parts of the region, particularly the remote parts are less studied. Moreover, application of coarse resolution of climate datasets from GCMs or RCMs (Regional Climate Models) can only provide average information on a global or regional scale, respectively. Therefore, for a better understanding of climate variability and for developing climate change adaptation measures at a local scale, climate information with high spatial resolution and temporal coverage are required.

Globally, in order to overcome the data challenges, a number of climate data products based on remote sensing (e.g., satellite-based rainfall products) such as Climate Hazards Group InfraRed Precipitation (CHIRP) and CHIRP with Station data (CHIRPS) (Funk et al., 2015) are developed for climate and hydrological studies. In addition, for Africa, a number of high-resolution satellite-based rainfall products such as the African Rainfall Climatology (Novella et al., 2013), Tropical Applications of Meteorology using Satellite and ground-based observations (TAMSAT) African Rainfall Climatology And Time series (TARCAT) (Maidment et al., 2017; Maidment et al., 2014; Tarnavsky et al., 2014), and Enhancing National Climate Services (ENACTS) (Dinku et al., 2014) are available at different spatial and temporal resolutions. The products differ in their development process (e.g., methodology, input data), temporal and spatial resolution, and spatial and temporal coverages. Therefore, before direct application of the products, assessing their accuracy by comparison with observed data is a prerequisite to identify the most accurate product and to produce valuable results. Hence, in our previous study (Gebrechorkos et al., 2018b), we evaluated different products based on climate models (RCMs), reanalysis, and satellite-based rainfall estimations such as CHIRPS and the African Rainfall Climatology. Finally, two products (for rainfall and maximum and minimum temperature) with high resolution (spatial and temporal) and coverage (spatial and temporal) were selected after a detailed evaluation over 21 regions of East Africa. In this study, therefore, using the selected datasets we assessed the variability in rainfall and maximum and minimum temperature (T-max and T-min) on decadal, seasonal, and annual time scales. In addition, the impact of large-scale climate variables such as the El Nĩno Southern Oscillation (ENSO) indices 
(e.g., Nĩno3.4) on rainfall variability and droughts are assessed. The results help identify areas with high variability in rainfall and an increase in droughts and develop adaptation measures at a local scale. In addition, the results will allow assessing the application of remote sensing and reanalysis based climate data products in climate and hydrological studies by comparing the results with historical observations (e.g., drought and flood events).

\section{z. 2 Study area and data}

\subsubsection{Study area}

The study is conducted in East Africa, also called the Greater Horn of Africa, particularly in Ethiopia, Kenya, and Tanzania (Fig. 1). The region is characterized by diverse topography and climate (e.g., rainfall varies within tens of kilometres) (WWF, 2006). The region is heavily dependent on rainfall and agriculture is the main sector. The commonality in the region is the occurrence of droughts and floods which is affecting millions of people (Nicholson, 2016). In this region, when extreme events (flood and droughts) occur within the same year, they make a devastating impact on the population (Nicholson, 2017). Most countries in East Africa experience rainy seasons during March--May (MAM) and October--December (OND). The MAM and OND rains are also called the long and short rains, respectively. MAM and OND contribute about 70\% and $20 \%$, respectively, of the total annual rainfall in East Africa (WWF, 2006). Moreover, the northern parts of Ethiopia receive a significant amount of rainfall during June--September (JJAS, boreal summer) (Camberlin and Philippon, 2002; Daron, 2014).

\section{alt-text: Fig. 1}

\section{Fig. 1}

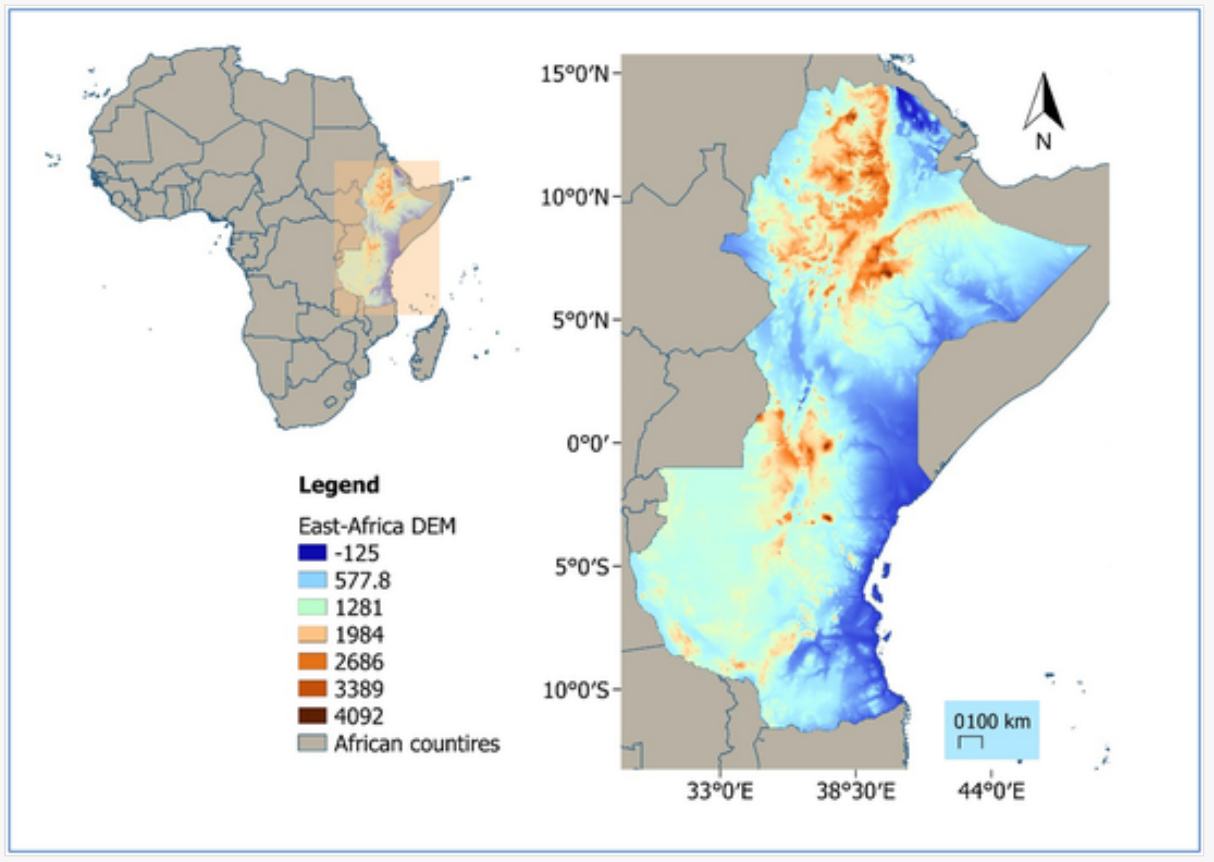




\subsubsection{Data}

In this study, high-resolution gridded data for precipitation and T-max and T-min are used. The products are selected based on our earlier study (Gebrechorkos et al., 2018b) evaluating and assessing the quality and accuracy of multiple climate data products available on a regional (Africa) and global scale. Due to the limited availability of ground station data, our previous study was mainly designed to assess and identify the most accurate climate data products by comparison with the available ground station data on multiple time scales (daily, 10-days, and monthly) and using different approaches (e.g., station to grid-cell and station average to area average). Multiple methods such as statistical (e.g., correlation, errors, and biases) and widely used graphical (e.g., Taylor-diagram) methods were used to identify the most accurate products. During the evaluation, for rainfall, other characteristics such as number and amount of dry and wet days were used. The evaluation, the most comprehensive to date, was conducted over 21 regions of East Africa. Finally, based on the different methods and approaches used, two products, i.e. CHIRPS for rainfall and the Observational Reanalysis Hybrid (OR) for T-max and T-min, were selected to be used in climate and hydrological studies in areas where station data is limited.

CHIRPS version 2 is a new quasi-global (ranging from $50^{\circ} \mathrm{S}$ to $50^{\circ} \mathrm{N}$ ) precipitation dataset developed mainly for monitoring of extremes and to assess the hydrological impact of changes in precipitation (Funk et al., 2015 ). The product is available at a high spatial resolution (up to $0.05^{\circ}$ ) and on multiple time scales (e.g., daily to monthly) from 1981 to present. CHIRPS is based on long-term precipitation estimations obtained from infrared Cold Cloud Duration (CCD). The CCD based rainfall estimates used in CHIRPS is first calibrated using the Tropical Rainfall Measuring Mission Multi-satellite Precipitation Analysis (Huffman et al., 2007). Ground data from filed based meteorological stations (e.g., Global Telecommunication System gauges) are incorporated in CHIRPS in two phases. According to Funk et al. (2015), the best available daily and monthly station data are blended with pentadal and monthly CCD based rainfall estimates to develop a preliminary product with two-day latency (i.e., phase one) and final product with three-week latency (i.e., phase two), respectively. Due to the inclusion of multiple ground observations in the development process, the products fall between rainfall products that are heavily interpolated gauges and sparse gauges blended with satellitebased rainfall products (Funk et al., 2015). The data is freely available from the Climate Hazards Group (http:// chg.geog.ucsb.edu/data/chirps/).

OR (Sheffield et al., 2006) is a widely used global meteorological forcings developed to drive hydrological and land-surface models. The observation-based product is developed by a spatial downscaling of the National Centers for Environmental Prediction-National Center for Atmospheric Research (NCEP-NCAR) reanalysis data (Kalnay et al., 1996) using a bilinear interpolation up to a resolution of $0.1^{\circ}$ (Chaney et al., 2014; Sheffield et al., 2006). OR is corrected for biases and, errors and temporal inhomogeneities are removed using quality-controlled field-based ground observations. The OR data is available at different temporal resolution (3-hourly to monthly) from Princeton University (http://hydrology.princeton.edu/data.php) from 1948- to 2012. In addition, Sea Surface Temperature (SST) anomalies for the Nĩno3.4 and Indian Ocean Dipole Mode Index (IOD) are obtained from the Global Climate Observing System (GCOS). The Nĩno3.4 is the most commonly used index to define the ENSO events (El Niño and La Niña events) (Trenberth et al., 2019). Nĩno3.4 is the average SST observed over the region $5^{\circ} \mathrm{S}$ to $5^{\circ} \mathrm{N}$ and $120^{\circ} \mathrm{W}$ to $170^{\circ} \mathrm{W}$ and indicates the warm 
and cold phases of the abnormal temperature of the region. Similarly, IOD measures the temperature difference between the western pole (Arabian Sea) and eastern pole (eastern Indian Ocean south of Indonesia). The variation in SST contributes to the variability in rainfall (Paul and Rashid, 2017) and its impact on rainfall variability is significant in East Africa, India, and Indonesia (Lim and Hendon, 2017). The SST anomalies for the Nĩno3.4 and IOD is computed from the Hadley Centre Global Sea Ice and Sea Surface Temperature (HadISST1.1) dataset (Rayner et al., 2003) and it is available from the NOAA earth system research laboratory working group on surface pressure (https://www.esrl.noaa.gov/psd/gcos_wgsp/).

\section{3 Methodology}

The Climate data Operator (CDO) (Schulzweida et al., 2009) is used to merge and aggregate multiple NetCDF files and compute monthly and annual average (temperature) and sums (precipitation). CDO combines multiple command line operators to analyze and manipulate different climate datasets in different formats such as NetCDF and GRIB.

The monthly total rainfall and monthly average T-max and T-min were computed using CDO for the periods January-_February (JF), March-_May (MAM), June-_September (JJAS), and October-_December (OND) for seasonal variability analysis. In addition, the monthly data is used for annual and decadal variability analysis in rainfall, T-max, and T-min. Seasonal, annual, and decadal variabilities are assessed by computing the anomalies as a departure from their long-term mean for both rainfall, T-max, and T-min. For seasonal and annual variability analysis, the long-term mean is computed from 1981- to 2016 and 1981--2012 for precipitation and T-max and T-min, respectively. For decadal analysis, the period from 1981- to 2010 is used for both rainfall and T-max and T-min. Anomalies accurately display climate variability compared to absolute values and allow comparison between locations (Camuffo et al., 2013; NOAA, 2017). To assess the spatial variability in each grid cell, the standard deviation is used, which helps identify the most and less variable areas of the region.

In addition, the standardized precipitation index (SPI) (McKee et al., 1993) is used to indicate meteorological droughts, precipitation deficit, and wetter climate during the study period. According to Labudová et al. (2017) , SPI, compared to other drought indices, is globally used and suitable, due to its simplicity and data requirement, for application in agriculture and water management.

SPI is computed by fitting the observed monthly rainfall (from datasets longer than 30 years) to a probability distribution which is finally converted into an index. The index represents the number of deviations by which observed rainfall anomalies deviates from the long-term mean (Keyantash et al., 2018). The SPI can be used for a range of time periods, for example, the three and six months SPI indicates seasonal to medium-term patterns of precipitation and can be used to reflect the condition of soil moisture and agricultural droughts. In addition, longer periods such as 12--24 months indicate the long-term patterns in precipitation and can be used for conditions of groundwater, reservoirs, and streamflows. Compared to the Palmer drought index (Palmer, 1965), another widely used drought index, the six-month SPI is more sensitive at a given time scale and the 12-month SPI provides similar outputs. Droughts are indicated by SPI values of less than $=-1.0$ : extreme $(<-$ $=2$ ), severe (- -1.5 to $-=1.99)$, moderate (- $=1.0$ to $=1.49$ ), and mild (0 to $-=0.99)$ droughts. In addition, wet events (e.g., floods) are indicated by SPI values of greater than 1.0 (WMO, 2012). Further, the trend package 
of the R Project for Statistical Computing (Pohlert, 2016) is used to detect change points in the annual time series of rainfall, T-max, and T-min and to compute the presence of a downward or upward trend $\left(P_{-}<\theta_{-} .05\right)$ in the SPI values.

\section{4. $\underline{4}$ Results}

\subsubsection{Decadal variability in rainfall and temperature}

For decadal analysis, the anomalies for each grid cell are computed as a departure from the mean of the period 1981-_2010 (decadal mean) of rainfall, T-max, and T-min and the results are classified as the 1980s, 1990s, and 2000s (Fig. 2). The results show that in the 1980s large parts of Ethiopia, particularly western, northern and northeastern parts were drier than during the 1990s and 2000s, and the 2000s were drier than 1990s. On the other hand, the central part of Ethiopia (Arsi Zone) is much wetter (anomalies up to $+200 \mathrm{~mm}$ ) in the 1980s compared to the 1990s and 2000s. In general, large parts of Ethiopia were drier in the 1980s (except Arsi Zone) and 2000s compared to the 1990s.

alt-text: Fig. 2

Fig. 2 


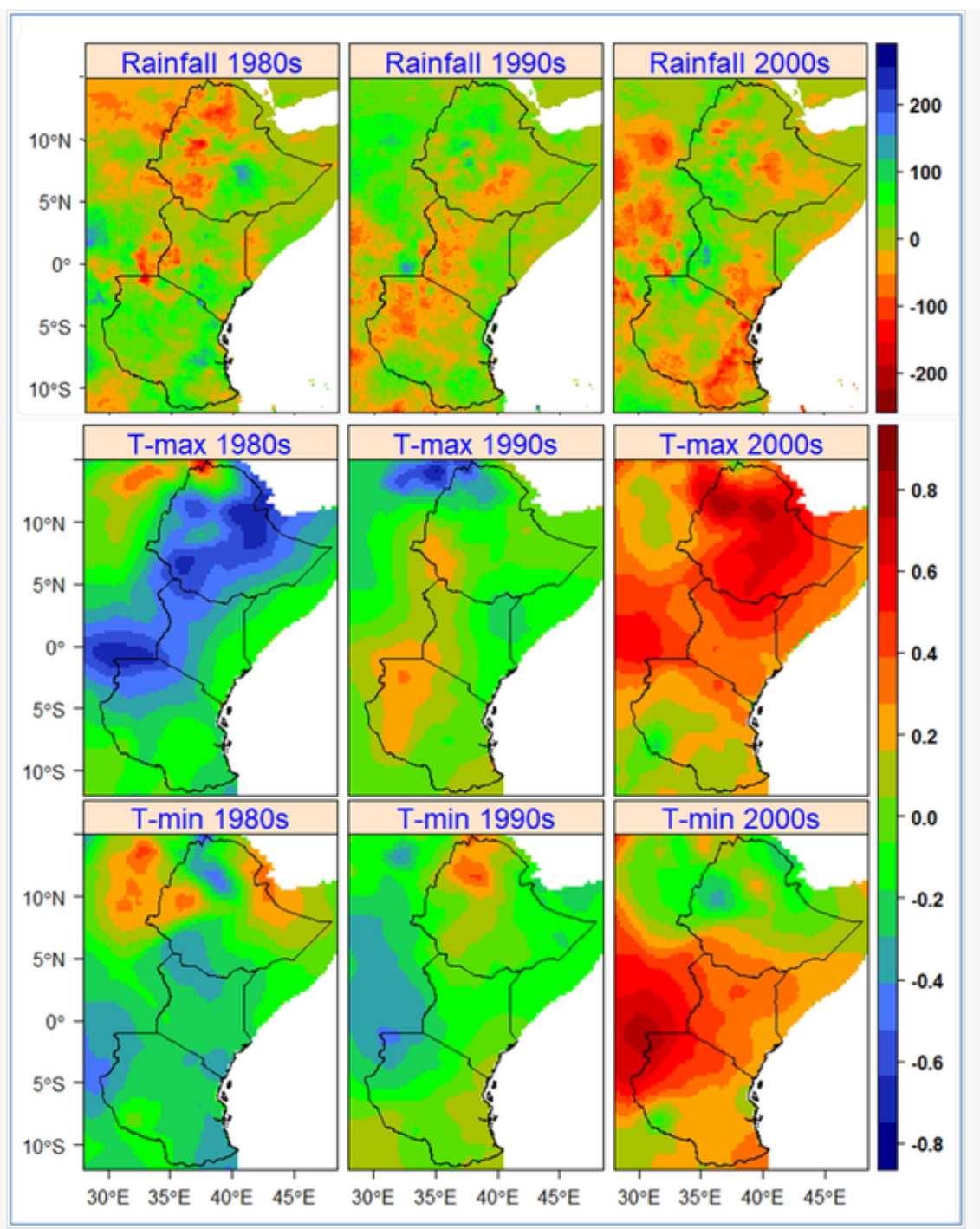

Decadal variation of rainfall (mm, top), T-max $\left({ }^{\circ} \mathrm{C}\right.$, middle) and $\mathrm{T}-\mathrm{min}\left({ }^{\circ} \mathrm{C}\right.$, bottom) for East Africa, particularly Ethiopia, Kenya, and Tanzania calculated as the deviation from the decadal mean (1981-_2000) based on CHIRPS and OR for rainfall and T-max and T-min, respectively.

In Kenya, the western parts were drier (anomalies up to - $=130 \mathrm{~mm}$ ) in the 1980s and 1990s compared to the decadal mean and the 2000s (anomalies up to $180 \mathrm{~mm}$ ). However, the eastern and southeastern parts of Kenya are drier (anomalies up to $-=110 \mathrm{~mm}$ ) in the 2000s compared to the decadal mean and also the 1980s and 1990s. Unlike to Ethiopia and Kenya, large parts of Tanzania were wetter in the 1980s (anomalies up to $+200 \mathrm{~mm}$ ) than the 1990s and 2000s. The western and northwestern parts Tanzania were drier in the 1990s compared to the 2000s, but the northern and northeastern parts are drier in the 2000s. On average, the rainfall in this region (averaged over Ethiopia, Kenya, and Tanzania) is decreased by $9.2 \mathrm{~mm}, 20 \mathrm{~mm}$, and $7.4 \mathrm{~mm}$ in the 2000s compared to the decadal mean, 1980s, and 1990s, respectively.

In addition to the decrease in rainfall in the 2000s compared to the 1990s, the region was much warmer during the 2000s than during the 1980s and 1990s (Fig. 2). T-max, particularly in Ethiopia and Kenya, showed an increase up to $0.9^{\circ} \mathrm{C}$ in the $2000 \mathrm{~s}$. On the contrary, T-max in the $1980 \mathrm{~s}$ was cooler (anomalies up to $=1.7^{\circ} \mathrm{C}$ ) than 1990s and 2000s in large parts of Ethiopia, Kenya, and Tanzania. Only in the southwestern parts of 
Tanzania (around Rukwa and Katavi), T-max was warmer during the 1990s compared to the 2000s and 1980s. In general, T-max showed an increasing tendency from the 1980s to 1990s and 2000s in large parts of the region with a maximum change in Ethiopia (anomalies up to $+0.9{ }^{\circ} \mathrm{C}$ ) and minimum change in Tanzania (anomalies up to $+0.1_{-}^{\circ} \mathrm{C}$ ).

Similar to the change in T-max, T-min in the 1980s was cooler (anomalies up to $=1.2{ }^{\circ} \mathrm{C}$ ) than in the $1990 \mathrm{~s}$ and 2000s in large parts of the region (Fig. 2). In Kenya and Tanzania, T-min showed an increasing tendency from the $1980 \mathrm{~s}$ to $2000 \mathrm{~s}$. However, in the western part of Ethiopia (around Benishangul Gumuz), T-min in the 2000 s was cooler (anomalies up to $-=0.6^{\circ} \mathrm{C}$ ) than $1980 \mathrm{~s}$ and $1990 \mathrm{~s}$. On the other hand, T-min was much warmer (anomalies up to $+0.5^{\circ} \mathrm{C}$ ) in the northern part of Ethiopia in the 1990s compared to the $1980 \mathrm{~s}$ and 2000s. Therefore, in Ethiopia, unlike the change in Kenya and Tanzania, T-min did not show an increasing or decreasing tendency but variability between the decades.

\subsubsection{Seasonal variability in rainfall}

In order to assess the seasonal variability in rainfall, the standard deviation is computed for each grid-cell (Fig. 3). The result shows strong seasonal variability (standard deviation up to $250 \mathrm{~mm}$ ) in rainfall during the long (MAM) and short (OND) rainy seasons. During MAM, the variability is higher in Tanzania, particularly in the southern and southeastern parts, and lower in Ethiopia (e.g., northern and eastern parts). Similarly, during OND variability is higher in Tanzania and the central part of Kenya compared to Ethiopia, which shows less variability in large part of the region. In Ethiopia, the highest variability (standard deviation up to $230 \mathrm{~mm}$ ) is observed in the northern part during JJAS compared to MAM and OND. During JF, which is the driest season in Ethiopia and Kenya, high variability is observed in Tanzania. In general, high variability is observed in Tanzania followed by Kenya during MAM and OND whereas the variability is higher in Ethiopia during JJAS.

alt-text: Fig. 3

\section{Fig. 3.Fig. 3}

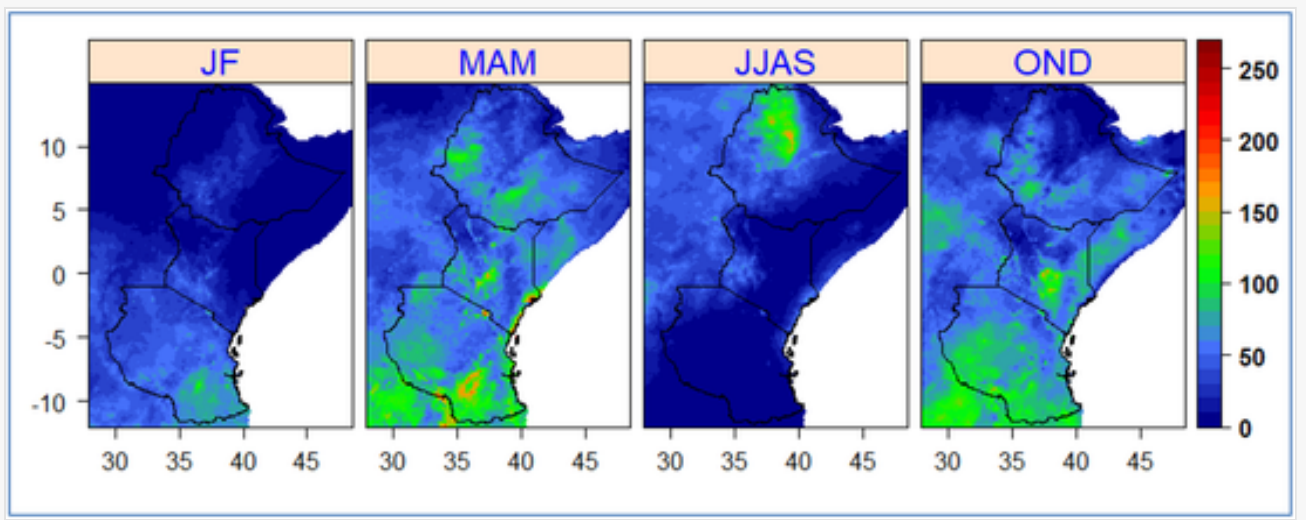

The standard deviation of seasonal rainfall (mm) in East Africa (Ethiopia, Kenya, and Tanzania) computed for each grid-cell (based on CHIRPS). 
On a country scale, spatially averaged over Ethiopia, Kenya, and Tanzania, the result shows a strong seasonal and annual variability in rainfall in Ethiopia, Kenya, and Tanzania during the period of 1981-_2016 (Fig. 4a). In Tanzania, the observed seasonal rainfall during MAM and OND are $366.6 \mathrm{~mm}$ and $292.6 \mathrm{~mm}$, respectively and this is higher than in Kenya and Ethiopia. Compared to MAM, JJAS is the most important rainy season for rain-fed agriculture in the northern and highlands of Ethiopia with average seasonal rainfall of $570.46 \mathrm{~mm}$. In this region, OND is the most variable season (anomalies up to $+330 \mathrm{~mm}$ and $=149 \mathrm{~mm}$ ), particularly in Kenya and Tanzania, followed by MAM (anomalies up to $+150 \mathrm{~mm}$ and $=100 \mathrm{~mm}$ ). In addition to the high variability, the relative change (Fig. $4 \mathrm{~b}$ ) is higher (up to $150 \%$ and_--_65\%) during OND than in other seasons. The rainfall variability in OND shows a significantly higher correlation with IOD in Ethiopia $(r=0.69)$, Kenya $(r=0.80)$, and Tanzania $(r=0.63)$ (Table 1). However, during MAM the Nĩno3.4 appeared to have the highest impact compared to IOD in Ethiopia and Kenya with a non-significant correlation of 0.31 and 0.26 , respectively (Table 1). During MAM, similar to the change in OND, the relative change is higher (up to $57 \%$ and $--=42 \%$ ) in Kenya and Ethiopia and lower in Tanzania (up to $23 \%$ and $-=-18 \%$ ).

alt-text: Fig. 4

Fig. 4

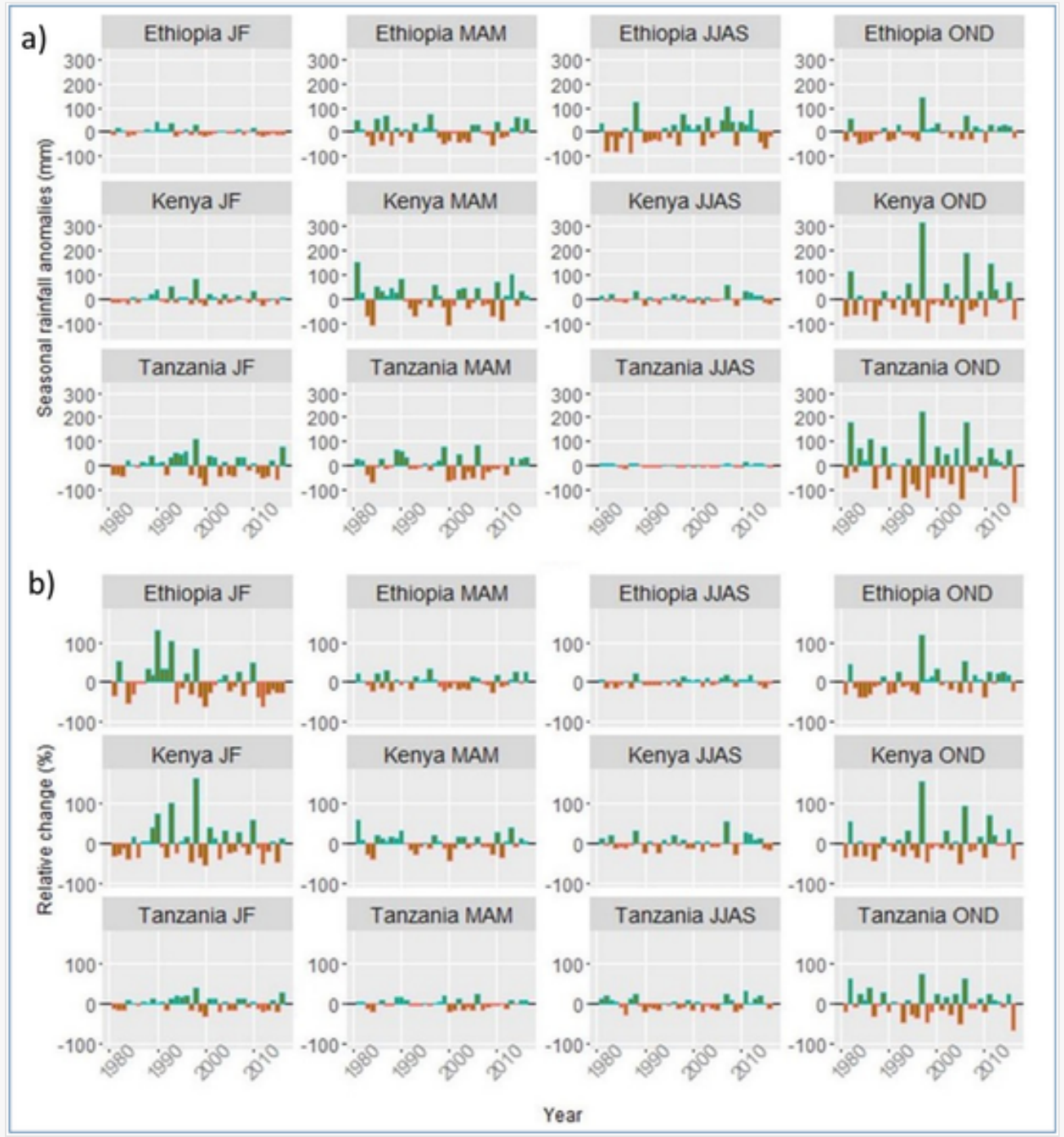


Seasonal rainfall anomalies (mm, a) and relative change (\%, b) in Ethiopia, Kenya, and Tanzania during the period of $1981--2016$ (based on CHIRPS). MAM and OND are the long and short rainy seasons, respectively. Dark filled red and cadet-blue bars are anomalies below and above the long-term mean (1981--2016). (For interpretation of the references to colour in this figure legend, the reader is referred to the web version of this article.)

alt-text: Table 1

Table 1

The presentation of Tables and the formatting of text in the online proof do not match the final output, though the data is the same. To preview the actual presentation, view the Proof.

Correlation (r) between seasonal rainfall and the Nĩno3.4 and IOD indices. MAM and OND are the long and short rainy seasons, respectively. A statistically significant correlation $\left(P_{-}<\theta_{-} .05\right)$ is indicated in bold.

\begin{tabular}{|l|l|l|l|l|l|}
\hline Region & Variables & JF & MAM & \multicolumn{1}{l}{ JJAS } & OND \\
\hline Ethiopia & Nĩno3.4 & $\mathbf{0 . 4 4}$ & 0.31 & $-=\mathbf{0 . 5 6}$ & 0.26 \\
\hline & IOD & 0.20 & 0.07 & $-=0.01$ & $\mathbf{0 . 6 9}$ \\
\hline Kenya & Nĩno3.4 & 0.28 & 0.26 & $\mathbf{0 . 3 6}$ & $\mathbf{0 . 3 8}$ \\
\hline & IOD & $\mathbf{0 . 3 3}$ & $=-0.10$ & 0.21 & $\mathbf{0 . 8 0}$ \\
\hline Tanzania & Nĩno3.4 & 0.25 & 0.10 & 0.30 & 0.32 \\
\hline & IOD & $\mathbf{0 . 3 7}$ & $=-0.14$ & 0.28 & $\mathbf{0 . 6 3}$ \\
\hline
\end{tabular}

In Ethiopia, similar to the observed variability during OND, rainfall variability during JJAS (anomalies up to $\pm-120 \mathrm{~mm}$ ) is significantly negatively correlated $(r=--=0.56)$ with Nĩno3.4. Even though JF is the driest season in Ethiopia and Kenya, Tanzania receives moderate rainfall during JF. Compared to Ethiopia and Kenya, rainfall variability during JF is higher (anomalies up to $+110 \mathrm{~mm}$ and_--_ $70 \mathrm{~mm}$ ) in Tanzania and significantly correlates with IOD $(r=0.37$ ). To the contrary, the relative change during JF is lower (up to $40 \%$ and---_29\%) in Tanzania and higher (up to $162 \%$ and--- 59\%) in Ethiopia and Kenya. Overall, compared to the dry seasons, short and long rainy seasons showed higher variability in rainfall.

\subsubsection{Annual variability in rainfall and temperature and droughts}

On the annual time scale, similar to seasonal, rainfall variability is higher in Tanzania and Kenya compared to Ethiopia (Fig. 5). In Ethiopia, variability is higher (standard deviation up to $230 \mathrm{~mm}$ ) in the central-western and northern parts and lower in the eastern part. Except for the northwestern part, large parts of Kenya show high variability up to a deviation of $430 \mathrm{~mm}$. Furthermore, large parts of Tanzania, except the central parts of the country (Iringa and Dodoma), show high variability up to a deviation of $345 \mathrm{~mm}$. T-max and T-min, on the other hand, show a similar pattern of variability: higher in western and lower in the eastern part of the region ( Fig. 5). The variability in T-max and T-min is higher (standard deviation up to $1.2_{-}^{\circ} \mathrm{C}$ ) in the northern part of 
Ethiopia and southwestern parts of Tanzania compared to the other part of the region, particularly the eastern part, which shows less variability (standard deviation up to $0.4_{-}^{\circ} \mathrm{C}$ ).

alt-text: Fig. 5

Fig. 5

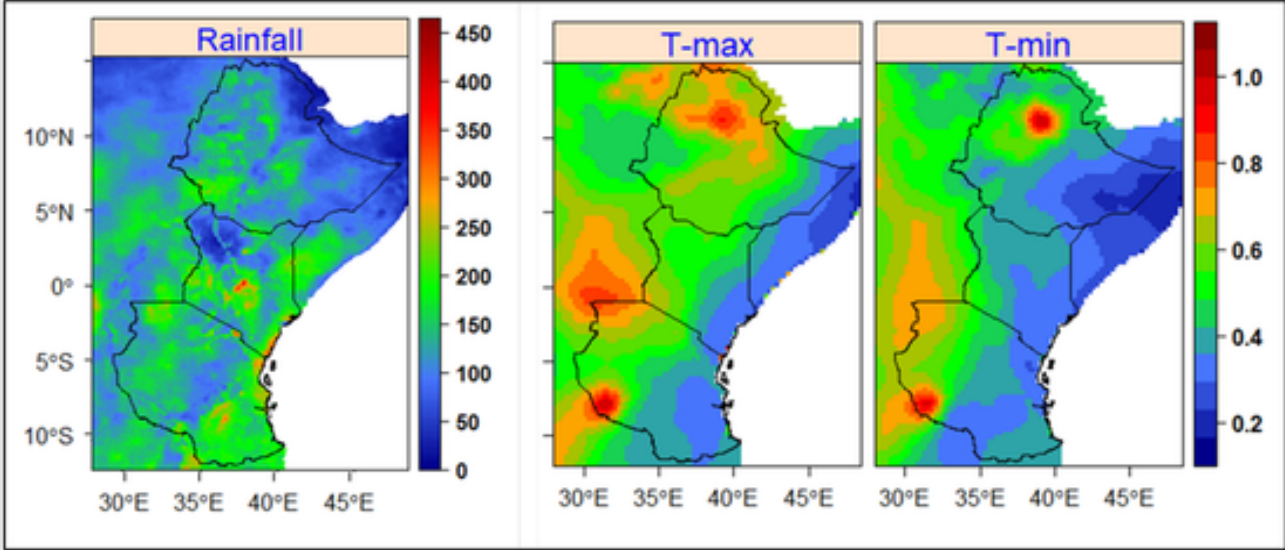

The standard deviation of annual rainfall (mm, based on CHIRPS) and T-max and T-min $\left({ }^{\circ} \mathrm{C}\right.$, based on OR) in East Africa (Ethiopia, Kenya, and Tanzania) computed for each grid-cell.

Taking the country average, rainfall variability on annual time scale is higher in Kenya (anomalies up to - 120 and +_230 mm) and Tanzania (up to $\pm 250 \mathrm{~mm}$ ) and lower in Ethiopia (Figs. 6 and 5). Annual rainfall variability in this region is lower during 2007-_2016 compared to 1981-_2006, particularly in Kenya and Tanzania. Similar to annual rainfall variability, variability in annual T-max and T-min is higher in Kenya and Tanzania and lower in Ethiopia (Fig. 6). The T-max annual average observed before 1995 is cooler (anomalies up to $-=0.7_{-}^{\circ} \mathrm{C}$ ) than the long-term mean (1979-_2012), particularly in Ethiopia and Kenya. On the other hand, the period after 1995 is warmer (anomalies up to $+0.70_{-}^{\circ} \mathrm{C}$ ) than the long-term mean in Ethiopia, Kenya, and Tanzania. In Ethiopia and Kenya, significant change points in T-max are detected in 1998 and 1999, respectively. Observed annual average values of T-min, on the other hand, were cooler (anomalies up to $=0.5_{-}^{\circ} \mathrm{C}$ ) and warmer (anomalies up to $+0.8_{-}^{\circ} \mathrm{C}$ ) than the long-term mean, particularly in Kenya and Tanzania, before and after 2000, respectively. In Kenya and Tanzania, significant change points in T-min are detected in 1994 and 2002, respectively, while only a non-significant change point is found in Ethiopia in 1990.

alt-text: Fig. 6 


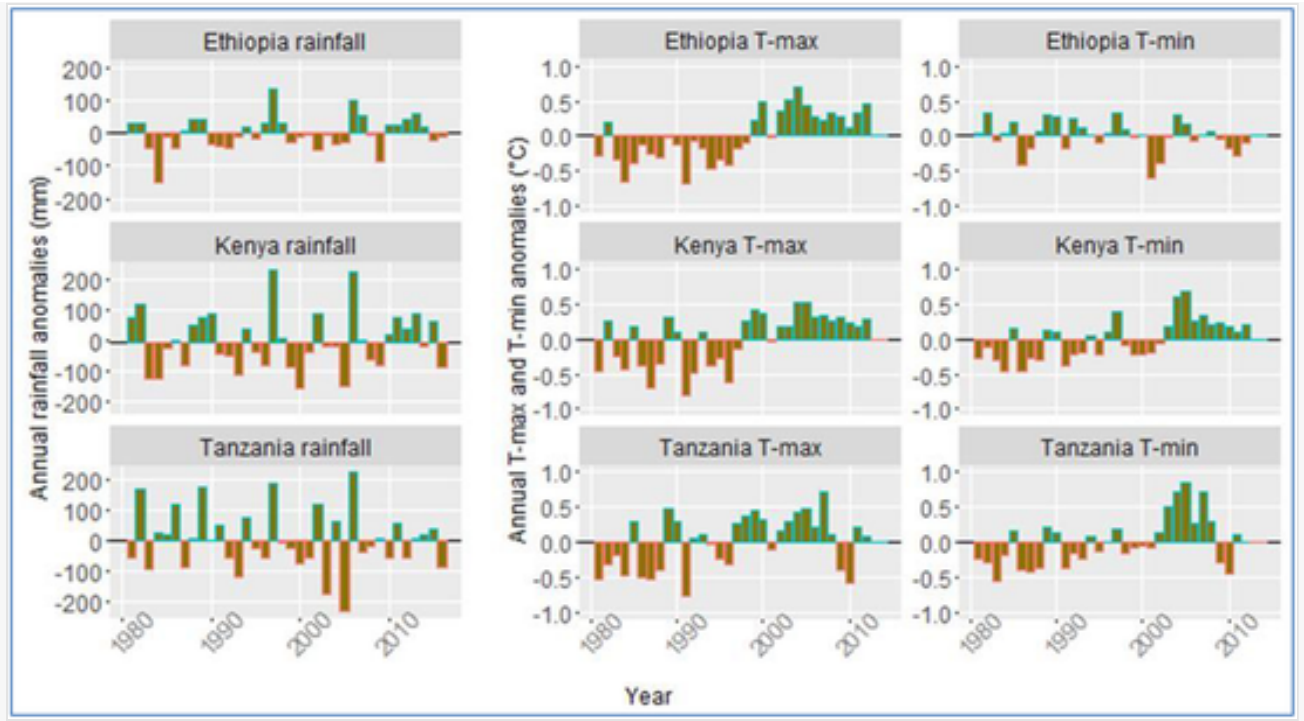

Annual rainfall (mm, left) and T-max and T-min $\left({ }^{\circ} \mathrm{C}\right.$, right) anomalies in Ethiopia, Kenya, and Tanzania. Dark filled red and cadetblue bars are anomalies below and above the long-term mean. Rainfall and T-max and T-min are based on CHIRPS (1981=-2016) and OR (1979--2012), respectively. (For interpretation of the references to colour in this figure legend, the reader is referred to the web version of this article.)

In addition to the observed high variability in seasonal and annual rainfall, the standardized precipitation index (SPI) showed considerable swings (wet and dry events) in Ethiopia, Kenya, and Tanzania (Fig. 7). The 12month SPI shows the most prominent drought years in Ethiopia, Kenya, and Tanzania. The observed severe droughts (e.g., 1984/1985, 1999/2000) and extreme floods (e.g., 1997/1998, 2007) in this region are linked to the respective negative and positive anomalies of the Niño3.4 (Fig. 7). For example, during MAM large parts of the region were much drier in 2015 compared to 1998 (Fig. 8). During MAM, large parts of Kenya (except the western part) and Tanzania were much wetter (SPI-3 up to 2.4) in 1998 than in 2015. In 2015, large parts of Ethiopia (except some parts of western and southeastern) and Tanzania were drier (SPI-3 up to --2.9) than 1998. Taking the country average, Fig. 7 clearly shows that the year 1998 is wetter than 2015 and this event is linked with the positive anomalies of the Niño3.4.

alt-text: Fig. 7 


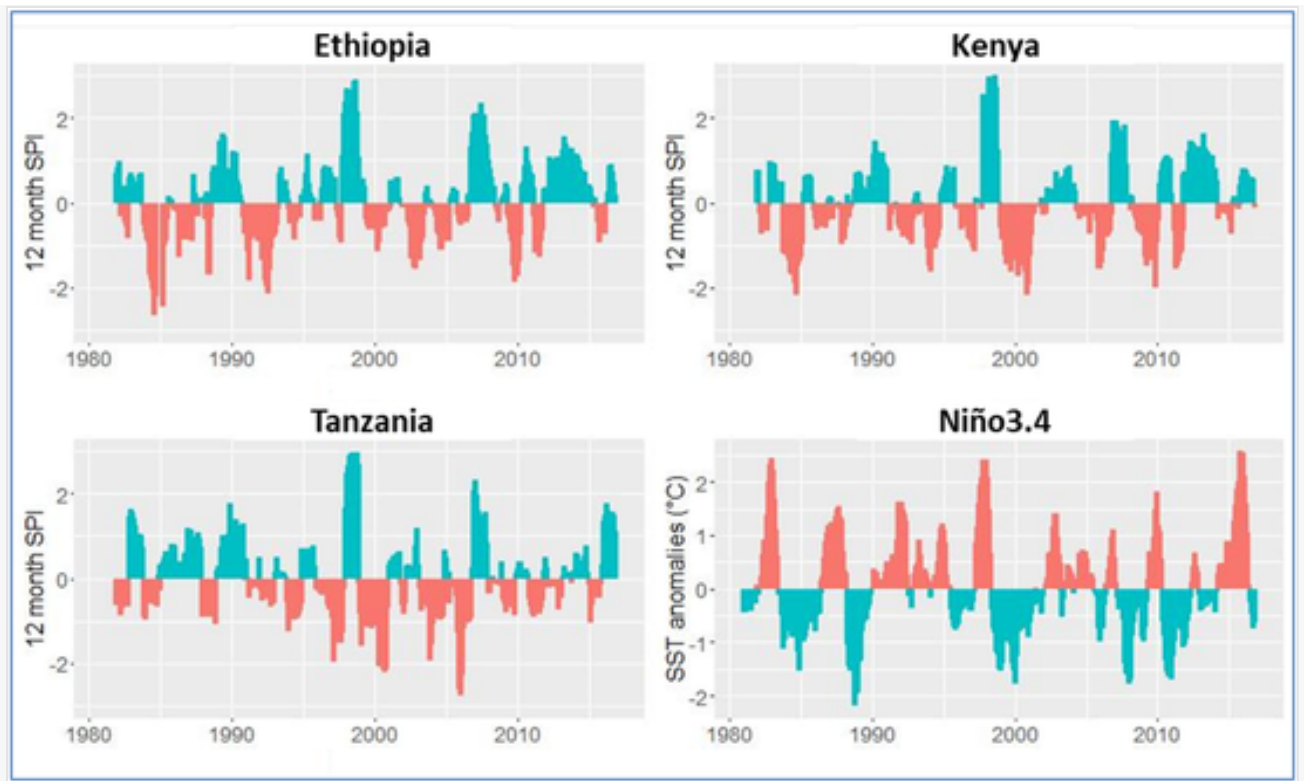

Drought index computed using the 12 months StandardisedStandardized Precipitation Index (SPI) for Ethiopia, Kenya, and Tanzania and monthly SST anomalies $\left({ }^{\circ} \mathrm{C}\right)$ of the Niño3.4 during 1981=-2016 based on CHIRPS.

alt-text: Fig. 8

\section{Fig. 8}

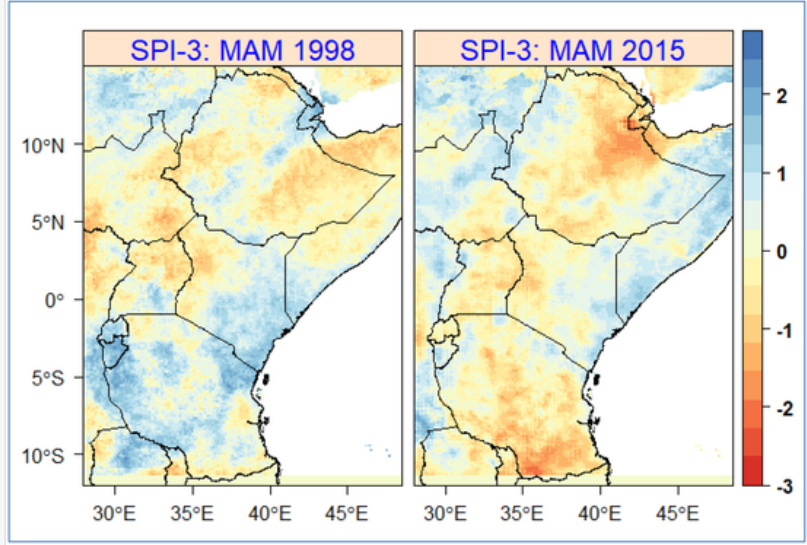

The 3-month SPI (SPI-3) for Ethiopia, Kenya, and Tanzania averaged over the long rainy season (MAM) for years 1998 (left) and 2015 (right).

On average (spatially averaged over the countries), the 12-month SPI indicates mild, moderate, severe, and extreme droughts of about 37\%,6\%,4\%, and 3\% of the study period (1981-_2016), respectively, in Ethiopia. In addition, mild, moderate, severe, and extreme droughts of $40 \%, 11 \%, 4 \%$, and $1 \%$, respectively, of the study period are observed in Kenya. In Tanzania, the 12-month SPI showed mild, moderate, severe, and extreme droughts of $42 \%, 6 \%, 2 \%$, and $3 \%$ of the study period, respectively. Moreover, the three (six) month SPI showed that more than $33 \%(31 \%), 11 \%(7.7 \%), 3.6 \%(3.3 \%)$, and $1.5 \%(1.7 \%)$ of the study period were experienced mild, moderate, severe, and extreme droughts, respectively, in Ethiopia, Kenya, and Tanzania. In 
general, the regional average of the 12 months SPI showed a significant increasing trend in Ethiopia and Kenya and a non-significant decreasing trend in Tanzania.

The long-term trend in the 3-, 6-, and 12-month SPI reveals that a large part of the region is facing an increasing trend in droughts (Fig. 9). In Fig. 9, the values of the trend in 3-, 6-, and 12-months SPI are given by multiplying with the length of time series (1981--2016) to improve the readability and quality of the maps. The trend analysis shows that large parts of Tanzania and eastern parts of Ethiopia and Kenya are getting drier and the change is statistically significant in large parts of the region. On the other hand, the western parts of Ethiopia and Kenya and northwestern parts of Tanzania are getting wetter and it is statistically significant.

alt-text: Fig. 9

\section{Fig. 9}

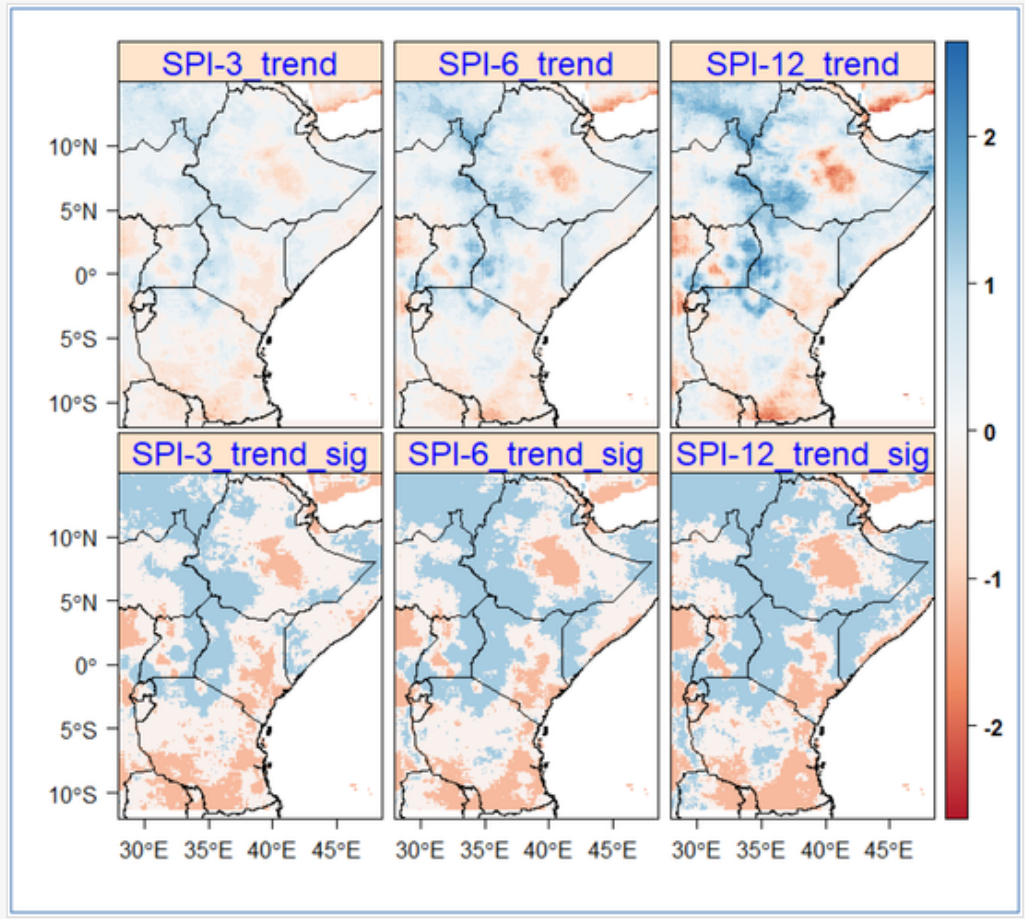

Long-term trends (upper map) in the 3 (SPI-3, left), 6 (SPI-6, middle), and 12 (SPI-12, right) months SPI for Ethiopia, Kenya, and Tanzania based on CHIRPS. The trend is given by multiplying the trend rate by the length of the study period (1981=-2016). The lower map shows the significance (sig) of the trend at $P_{-}<\theta_{-} .05$ and values 1,0 , and ${ }_{-}=-1$ show a significant increasing trend (blue), non-significant change (light), and significant decreasing trend (red), respectively. (For interpretation of the references to colour in this figure legend, the reader is referred to the web version of this article.)

\subsection{Discussion and conclusion}

In data-sparse regions such as Africa, satellite-based climate data products with high spatial and temporal resolution and accuracy are widely used in hydro-climate studies (e.g. Camberlin et al., 2007; Rojas et al., 2011; Vrieling et al., 2016; Agutu et al., 2017; Cattani et al., 2018). However, some products, although biascorrected at a regional and global scale, face large bias and disagreement when compared with ground stations (Kimani et al., 2018). Studies in East Africa (Cattani et al., 2018; Maidment et al., 2015; Nicholson, 2017) 
concluded that application of different climate data products leads to a different conclusion on trends and variabilities in climate, particularly seasonal rainfall variability. Hence, before direct application of the currently available satellite and reanalysis based climate data products in climate and hydrological studies, it is crucial to check their accuracy such as by comparing with ground station data to identify the most accurate products for the region of interest. Therefore, in this study, we applied products with high accuracy (e.g., high correlation and lower biases and errors) and spatial and temporal resolution identified after a comprehensive data evaluation for East Africa (Gebrechorkos et al., 2018b). On a regional scale, some of the general results are already available, but this study provides a more detailed analysis (local to region scale) in terms of spatial resolution and temporal coverage allowing for development of location-based adaptation measures to manage impacts of seasonal variability in rainfall and extreme events (e.g., droughts).

Based on the products used in this study, a strong variability in seasonal, annual, and decadal rainfall and an increasing trend in droughts is observed in large parts of East Africa. In this study, we provide a more detailed analysis, compared to studies based on coarse resolution (Haile et al., 2019), to help accurately identify areas facing high variability in rainfall and an increasing tendency in temperature and droughts. According to Menghestab (2005), the variability of large scale climate variables (e.g., ENSO) is responsible for the occurrence of droughts in East Africa by modulating the rainfall patterns. In this region, concerning seasonal variability in rainfall, clearly OND (short-rainy season) followed by MAM (long rainy season) is the most variable seasons in East Africa. Compared to Ethiopia and Tanzania, rainfall variability during OND and MAM is higher in Kenya (anomalies up to $+220 \mathrm{~mm}$ and $=160 \mathrm{~mm}$ ). According to Nicholson (2017) and WWF (2006), rainfall during MAM is more reliable and most of the inter-annual variability, while receiving less rainfall, comes during OND with a coefficient of variability of $74 \%$. Rainfall variability during JJAS in Kenya and Tanzania and JF in Ethiopia and Kenya was found to be less variable compared to MAM and OND. Similar to our finding, other studies (Abram et al., 2008; Herrero et al., 2010; Liebmann et al., 2014; Seregina et al., 2014; WMO, 2015) based on different datasets and covering different areas of the region, showed a strong connection between rainfall variability during OND and IOD. Several studies (Funk et al., 2008; Lyon and DeWitt, 2012; Niang et al., 2014; Williams and Funk, 2011) concluded that rainfall variability during MAM is linked to large-scale climate variables such as ENSO and IOD. The most important rainy season (JJAS) in the highlands and northern parts of Ethiopia, which is less studied in this region (Nicholson, 2017), showed a significant negative correlation (--56\%) with ENSO and this agrees with the finding of Degefu et al. (2017). The impact of ENSO and IOD is not only limited to seasonal rainfall variability but showed a significant impact on decadal climate variability (Daron, 2014; Lyon and DeWitt, 2012; Williams and Funk, 2011). Hence, unlike to T-max and T-min that shows an increasing tendency from the 1980s to 2000s, rainfall shows higher decadal variability. For example, large parts of Ethiopia were drier in the 1980s and 2000s, but wetter in the 1990s. Moreover, the western parts of Kenya were wetter in the 1980s and 2000s compared to the 1990s. In this region, the long-term trend analysis in rainfall and temperature also show a non-significant change in seasonal and annual rainfall and increasing trend in T-max and T-min in large parts of East Africa ( Gebrechorkos et al., 2019b). In addition to the positive change in T-max and T-min, significant change points are detected in T-max (Ethiopia and Kenya) and T-min (Kenya and Tanzania), which, taken together, are clear signals of warming in the region. The increase in T-max and T-min is apparent from 1997- to 2000 which showed positive anomalies up to $0.8_{-}^{\circ} \mathrm{C}$. The observed increase in T-max and T-min from the $1980 \mathrm{~s}$ to $2000 \mathrm{~s}$ at 
decadal and annual time scales is in line with global warming and other studies covering different parts of the region (Camberlin, 2017; CDKN, 2014; Daron, 2014; IPCC, 2013; WMO, 2013). The overall result clearly shows that the occurrence of droughts in this region is associated with the observed variability in rainfall and the large-scale climate variables particularly the Nino3.4 and IOD indices. As a result, drought events are becoming one of the major issues in the regions strongly affecting the economy and environment as a whole.

Applications of satellite-based rainfall products with high resolution and accuracy, therefore, allow detecting extreme events such as droughts and floods at a local scale. As shown in Fig. 7, using CHIRPS, the most severe drought years (e.g., 1984/1985 and 1999/2000) were accurately detected. The drought in 1984/1985, for example, is one of the most serious and devastating events in this region, which lead to the death (starvation) of millions (greater than 10 million) of people and countless animals (Kebbede and Jacob, 1988; Haile et al., 2019). In addition, the 1984/1985 drought event led parts of the region, particularly Ethiopia, to be completely dependent on external food aids to feed more than 5.8 million of people (Haile et al., 2019). In addition to droughts, years with extreme rainfall events (e.g., 1997/1998) were detected by using CHIRPS. According to Cattani et al. (2018) and EM-DAT (2019), the floods in 1997/1998 and droughts in 2006 and 2016 led to the death of 2906 people and about 24 million of people faced critical food security issues, respectively. In general, the accuracy of CHIRPS in detecting the extreme events (drought and floods) indicates the applicability of the product in hydrological modelling to detect and forecast droughts and floods in areas with limited ground station data (e.g., spatial and temporal coverage, quality, and accessibility). Overall, the finding, high variability in rainfall (seasonal-decadal) and an increase in T-max and T-min, clearly supports the need to develop adaptation measures at a local scale and raise awareness on sectors such as agriculture and water resource to mitigate the impacts.

\section{Declaration of Competing Interest}

None.

\section{References}

The corrections made in this section will be reviewed and approved by journal production editor.

WMO, 2015. The Climate in Africa: 2013 (No. 1147). Geneva, Switzerland.

ActionAid. East Africa Drought and Food Crisis - Two Years On. [WWW Document]. URL http://ww w.actionaid.org/2013/07/east-africa-drought-and-food-crisis-two-years, 2016. (accessed 12.19.16).

EM-DAT. EM-DAT | The international disasters databaseEM-DAT $\mid$ the International Disasters

Database. [WWW Document]. URL- https://www.emdat.be/--_2019. (accessed 2.21.19).

M-DAT, 2019. EM-DAT $\mid$ The international disasters database [WWW Document]. URL https://www.emdat.be/ (accessed 2.21.19). 
Abram, N.J., Gagan, M.K., Cole, J.E., Hantoro, W.S., Mudelsee, M., 2008. Recent intensification of tropical climate variability in the Indian Ocean. Nat. Geosci. 1, 849-853. doi:10.1038/ngeo357.

Agutu, N.O., Awange, J.L., Zerihun, A., Ndehedehe, C.E., Kuhn, M., Fukuda, Y., 2017. Assessing multi-satellite remote sensing, reanalysis, and land surface models' products in characterizing agricultural drought in East Africa. Remote Sens. Environ. 194, 287-302. doi:10.1016/j.rse.2017.03.041.

Camberlin, P., 2017. Temperature trends and variability in the Greater Horn of Africa: interactions with precipitation. Clim. Dyn. 48, 477-498. doi:10.1007/s00382-016-3088-5.

Camberlin, P., Philippon, N., 2002. The East African March-May Rainy Season: associated atmospheric dynamics and predictability over the 1968-97 Period. J. Clim. 15, 1002-1019. doi:10.1175/15200442(2002)015<1002:TEAMMR>2.0.CO;2.

Camberlin, P., Martiny, N., Philippon, N., Richard, Y., 2007. Determinants of the interannual relationships between remote sensed photosynthetic activity and rainfall in tropical Africa. Remote Sens. Environ. 106, 199-216. doi:10.1016/j.rse.2006.08.009.

Camuffo, D., Bertolin, C., Diodato, N., Cocheo, C., Barriendos, M., Dominguez-Castro, F., Garnier, E., Alcoforado, M.J., Nunes, M.F., 2013. Western Mediterranean precipitation over the last 300 years from instrumental observations. Clim. ChangeClim. Chang. 117, 85-101. doi:10.1007/s10584-012-0539-9.

Cattani, E., Merino, A., Guijarro, J.A., Levizzani, V., 2018. East A friea rainfall trends and variability 19832015 Using Three long-term satellite produtsEast Africa rainfall trends and variability 19832015 using three long-term satellite products. Remote Sens. 10, 931. doi:10.3390/rs10060931.

CDKN, 2014. The IPCC's Fifth Assessment Report: Whats in it for Africa.

Chaney, N.W., Sheffield, J., Villarini, G., Wood, E.F., 2014. Development of a high-resolution gridded daily meteorological dataset over Sub-Saharan Africa: spatial analysis of trends in climate extremes. J. Clim. 27, 5815-5835. doi:10.1175/JCLI-D-13-00423.1.

Daron, J.D., 2014. Regional Climate Messages: East AfrieaRegional climate Messages: East Africa. In: Seientific report from the CARIAA Adaptation at Seale in Semi-Arid Regions (ASSAR) ProjectScientific Report from the CARIAA Adaptation at Scale in Semi-Arid Regions (ASSAR) Project. Africa and Asia, Ottawa, ON, Collaborative Adaptation Research Initiative in.

Degefu, M.A., Rowell, D.P., Bewket, W., 2017. Teleconnections between Ethiopian rainfall variability and global SSTs: observations and methods for model evaluation. Meteorol. Atmospheric Phys. 129, 173-186. doi:10.1007/s00703-016-0466-9.

Dinku, T., Block, P., Sharoff, J., Hailemariam, K., Osgood, D., del Corral, J., Cousin, R., Thomson, M.C., 2014. Bridging critical gaps in climate services and applications in Africa. Earth Perspect. 1, 15. doi:10.1186/2194-6434-1-15. 
Endris, H.S., Omondi, P., Jain, S., Lennard, C., Hewitson, B., Chang'a, L., Awange, J.L., Dosio, A., Ketiem, P., Nikulin, G., Panitz, H.-J., Büchner, M., Stordal, F., Tazalika, L., 2013. Assessment of the performanee of CORDEX regional Climate models in simulating East $A$ friean rainfallAssessment of the performance of CORDEX regional climate models in simulating East African rainfall. J. Clim. 26, 8453-8475. doi:10.1175/JCLI-D-12-00708.1.

Endris, H.S., Lennard, C., Hewitson, B., Dosio, A., Nikulin, G., Panitz, H.-J., 2015. Teleconnection responses in multi-GCM driven CORDEX RCMs over Eastern Africa. Clim. Dyn. 46, 2821-2846. doi:10.1007/s00382-015-2734-7.

FAO, 2014. Adapting to elimate change through land and water management in Eastern $\Lambda$ frieaAdapting to Climate Change through Land and Water Management in Eastern Africa. Food and Agricultural Organization of the United Nations and World Bank, Rome.

Fer, I., Tietjen, B., Jeltsch, F., Wolff, C., 2017. The influence of El Niño-Southern Oscillation regimes on eastern African vegetation and its future implications under the RCP8.5 warming scenario. Biogeosciences 14, 4355-4374. doi:10.5194/bg-14-4355-2017.

Funk, C., Dettinger, M.D., Michaelsen, J.C., Verdin, J.P., Brown, M.E., Barlow, M., Hoell, A., 2008. Warming of the Indian Ocean threatens eastern and southern African food security but could be mitigated by agricultural development. Proc. Natl. Acad. Sci. 105, 11081-11086. doi:10.1073/pnas.0708196105.

Funk, C., Peterson, P., Landsfeld, M., Pedreros, D., Verdin, J., Shukla, S., Husak, G., Rowland, J., Harrison, L., Hoell, A., Michaelsen, J., 2015. The climate hazards infrared precipitation with stations-a new environmental record for monitoring extremes. Sci. Data 2, 150066. doi:10.1038/sdata.2015.66.

Gebrechorkos, S.H., Hülsmann, S., Bernhofer, C., 2018. Changes in temperature and precipitation extremes in Ethiopia, Kenya, and Tanzania. Int. J. Climatol. 39, 18-30. doi:10.1002/joc.5777.

Gebrechorkos, S.H., Hülsmann, S., Bernhofer, C., 2018. Evaluation of multiple climate data sources for managing environmental resources in East Africa. Hydrol. Earth Syst. Sci. 22, 4547-4564. doi:10.5194/hess-22-4547-2018.

Gebrechorkos, S.H., Hülsmann, S., Bernhofer, C., 2019. Regional climate projections for impact assessment studies in East Africa. Environ. Res. Lett. 14, 044031. doi:10.1088/1748-9326/ab055a.

Gebrechorkos, S.H., Hülsmann, S., Bernhofer, C., 2019. Long-term trends in rainfall and temperature using high-resolution climate datasets in East Africa. Sci. Rep. 9, 1-9. doi:10.1038/s41598-019-479338.

Haile, G.G., Tang, Q., Sun, S., Huang, Z., Zhang, X., Liu, X., 2019. Droughts in East Africa: Causes, impacts and resilience. Earth-Sci. Rev. 193, 146-161. doi:10.1016/j.earscirev.2019.04.015. 
Herrero, M., Ringler, C., van de Steeg, J.A., Thornton, P.K., Zhu, T., Bryan, E., Omolo, A., Koo, J., Notenbaert, A.M.O., 2010. Elimate variability and elimate change and their impaets on Kenya's agrieultural seetor (Report)Climate Variability and Climate Change and their Impacts on Kenya's Agricultural Sector (Report). ILRI.

Huffman, G.J., Bolvin, D.T., Nelkin, E.J., Wolff, D.B., Adler, R.F., Gu, G., Hong, Y., Bowman, K.P., Stocker, E.F., 2007. The TRMM multisatellite preeipitation analysis (TMPA): quasi-global, multiyear, eombined-sensor preeipitation Estimates at fine sealesThe TRMM multisatellite precipitation analysis (TMPA): quasi-global, multiyear, combined-sensor precipitation estimates at fine scales. J.

Hydrometeorol. 8, 38-55. doi:10.1175/JHM560.1.

IFPRI, 2009. Economywide Impacts of Climate Change on Agriculture in Sub-Saharan Africa. (climatechange-agriculture.pdf (No. 00873)).

IPCC, 2007. In: Solomon, S. (Ed.), et al., Climate Change 2007: The Physical Science Basis. Cambridge Univ. Press. WG1.

IPCC, 2013. Climate Change 2013: The Physical Science Basis (eds Stocker et al.) (WG1). Cambridge Univ Press.

Kalnay, E., Kanamitsu, M., Kistler, R., Collins, W., Deaven, D., Gandin, L., Iredell, M., Saha, S., White, G., Woollen, J., Zhu, Y., Leetmaa, A., Reynolds, R., Chelliah, M., Ebisuzaki, W., Higgins, W., Janowiak, J., Mo, K.C., Ropelewski, C., Wang, J., Jenne, R., Joseph, D., 1996. The NCEP/NCAR 40-Year Reanalysis Project. Bull. Am. Meteorol. Soc. 77, 437-471. doi:10.1175/15200477(1996)077<0437:TNYRP>2.0.CO;2.

Kebbede, G., Jacob, M.J., 1988. Drought, famine and the political economy of environmental degradation in Ethiopia. Geography 73, 65-70.

Keyantash, J., National Center for Atmospheric Research Staff (Eds.), 2018. The Climate Data Guide: Standardized Precipitation Index (SPI). NCAR UCAR Clim. WWW Document. URL. https://climatedat aguide.ucar.edu/climate-data/standardized-precipitation-index-spi (accessed 11.15.19).

Kimani, M.W., Hoedjes, J.C.B., Su, Z., 2018. Bayesian bias correetion of satellite rainfall Estimates for Elimate studiesBayesian bias correction of satellite rainfall estimates for climate studies. Remote Sens. 10, 1074. doi:10.3390/rs10071074.

Kotir, J.H., 2011. Climate change and variability in Sub-Saharan Africa: a review of current and future trends and impacts on agriculture and food security. Environ. Dev. Sustain. 13, 587-605. doi:10.1007/s10668-010-9278-0.

Labudová, L., Labuda, M., Takáč, J., 2017. Comparison of SPI and SPEI applicability for drought impact assessment on crop production in the Danubian Lowland and the East Slovakian Lowland. Theor. Appl. Climatol. 128, 491-506. doi:10.1007/s00704-016-1870-2. 
Liebmann, B., Hoerling, M.P., Funk, C., Bladé, I., Dole, R.M., Allured, D., Quan, X., Pegion, P., Eischeid, J.K., 2014. Understanding Reeent eastern horn of afriea rainfall variability and ehangeUnderstanding recent eastern horn of africa rainfall variability and change. J. Clim. 27, 86308645. doi:10.1175/JCLI-D-13-00714.1.

Lim, E.-P., Hendon, H.H., 2017. Causes and predietability of the Negative Indian Oeean Dipole and Its Impaet on La Niña During 2016Causes and predictability of the negative Indian Ocean Dipole and its Impact on La Niña during 2016. Sci. Rep. 7, 12619. doi:10.1038/s41598-017-12674-z.

Lyon, B., DeWitt, D.G., 2012. A recent and abrupt decline in the East African long rains. Geophys. Res. Lett. 39, L02702. doi:10.1029/2011GL050337.

Maidment, R.I., Grimes, D., Allan, R.P., Tarnavsky, E., Stringer, M., Hewison, T., Roebeling, R., Black, E., 2014. The 30 year TAMSAT African Rainfall Climatology And Time series (TARCAT) data set. J. Geophys. Res. Atmos. 119. 2014JD021927. doi:10.1002/2014JD021927.

Maidment, R.I., Allan, R.P., Black, E., 2015. Recent observed and simulated changes in precipitation over Africa. Geophys. Res. Lett. 42, 8155-8164. doi:10.1002/2015GL065765.

Maidment, R.I., Grimes, D., Black, E., Tarnavsky, E., Young, M., Greatrex, H., Allan, R.P., Stein, T., Nkonde, E., Senkunda, S., Alcántara, E.M.U., 2017. A new, long-term daily satellite-based rainfall dataset for operational monitoring in Africa. Sci. Data 4, 170063. doi:10.1038/sdata.2017.63.

McKee, T.B., Doesken, N.J., Kliest, J., 1993. The relationship of drought frequency and duration to time scales. In Proceedings of the. In: 8th Conference of Applied Climatology, 17-22 January, Anaheim, CA.

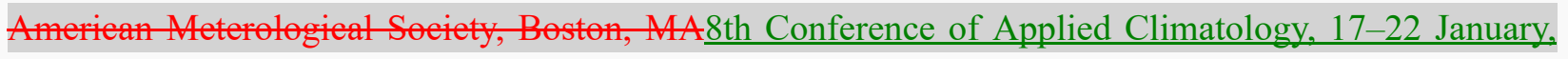
Anaheim, CA. American Meterological Society, Boston, MA. pp. 179-184.

Menghestab, H., 2005. Weather patterns, food security and humanitarian response in sub-Saharan Africa. Philos. Trans. R. Soc. B Biol. Sci. 360, 2169-2182. doi:10.1098/rstb.2005.1746.

Mpelasoka, F., Awange, J.L., Zerihun, A., 2018. Influence of coupled ocean-atmosphere phenomena on the Greater Horn of Africa droughts and their implications. Sci. Total Environ. 610-611, 691-702. doi:10.1016/j.scitotenv.2017.08.109.

Niang, I., Ruppel, O.C., Abdrabo, M.A., Essel, A., Lennard, C., Padgham, J., Urquhart, P., 2014. Africa. In: Barros, V.R. (Ed.), et al., Climate Change 2014: Impacts, Adaptation, and Vulnerability. Part B: Regional Aspects. Cambridge Univ. Press. WG2.

Nicholson, S.E., 2016. An analysis of recent rainfall conditions in eastern Africa. Int. J. Climatol. 36, 526-532. doi:10.1002/joc.4358.

Nicholson, S.E., 2017. Climate and climatic variability of rainfall over eastern Africa. Rev. Geophys. 55, 590-635. doi:10.1002/2016RG000544. 
NOAA. Climate Normals | National Centers for Environmental Information. (NCEI) formerly known as National Climatic Data Center (NCDC)Climate Normals | National Centers for EnvironmentalO Information (NCEI) Formerly Known as National Climatic Data Center (NCDC). [WWW Document]. URL-https://www.ncdc.noaa.gov/data-access/land-based-station-data/land-based-datasets/climate-normA als - -2 2017. (accessed 3.14.17).

2017. Climate Normals | National Centers for Environmental Information (NCEI) formerly known as National Climatic Data Center (NCDC) [WWW Document]. URL https://www.ncdc.noaa.gov/dataaccess/land-based-station-data/land-based-datasets/climate-normals (accessed 3.14.17).

N.S. Novella, W.M. Thiaw, N.S. Novella, W.M. Thiaw. African Rainfall Climatology Version 2 for Famine Early Warning Systems. [WWW Document]. Httpdxdoiorg101175JAMC--11-02381. URL htt p://journals.ametsoc.org/doi/abs/10.1175/JAMC-D-11-0238.1, 2013. (accessed 11.30.16).

Palmer, W.C., 1965. Meteorological Drought.

Paul, B.K., Rashid, H., 2017. Chapter Two - tropieal eyclones and Storm surgeschapter two - tropical cyclones and storm surges. In: Paul, B.K., Rashid, H. (Eds.), Climatic Hazards in Coastal Bangladesh. Butterworth-Heinemann, Boston, pp. 35-81. doi:10.1016/B978-0-12-805276-1.00002-8.

Pohlert, T., 2016. Non-Parametric Trend Tests and Change-Point Detection.

Rayner, N.A., Parker, D.E., Horton, E.B., Folland, C.K., Alexander, L.V., Rowell, D.P., Kent, E.C., Kaplan, A., 2003. Global analyses of sea surface temperature, sea ice, and night marine air temperature since the late nineteenth century. J. Geophys. Res. Atmos. 108, 4407. doi:10.1029/2002JD002670.

Rojas, O., Vrieling, A., Rembold, F., 2011. Assessing drought probability for agricultural areas in Africa with coarse resolution remote sensing imagery. Remote Sens. Environ. 115, 343-352. doi:10.1016/j.rse.2010.09.006.

Rowell, D.P., Booth, B.B.B., Nicholson, S.E., Good, P., 2015. Reeoneiling Past and futtre rainfall trends Over East $\Lambda$ frieaReconciling past and future rainfall trends over East Africa. J. Clim. 28, 9768-9788. doi:10.1175/JCLI-D-15-0140.1.

Salami, A., Kamara, A.B., Brixiova, Z., 2010. Smallholder Agriculture in East Africa: Trends, Constraints, and Opportunities. Africain Development Bank.

Schulzweida, U., Kornblueh, L., Quast, R., 2009. CDO - Climate Data Operators -Project Management Service. Max Planck Institute for Meteorology, Hamburg Germany.

Seregina, L., Ermert, V., Fink, A.H., Pinto, J.G., 2014. Frends and variability in East Afriean rainfall and temperature observations Trends and Variability in East African Rainfall and Temperature Observations. Presented at the EGU General Assembly Conference Abstracts, p. 6088.

Sheffield, J., Goteti, G., Wood, E.F., 2006. Development of a 50-Year High-Resolution Global Dataset of Meteorological Forcings for Land Surface Modeling. J. Clim. 19, 3088-3111. 
doi:10.1175/JCLI3790.1.

Sidahmed, A.E., 2018. Recent Trends in Drylands and Future Scope for Advancement. In: Gaur, M.K., Squires, V.R. (Eds.), Climate Variability Impacts on Land Use and Livelihoods in Drylands. Springer International Publishing, Cham, pp. 21-57. doi:10.1007/978-3-319-56681-8_2.

Tarnavsky, E., Grimes, D., Maidment, R., Black, E., Allan, R.P., Stringer, M., Chadwick, R., Kayitakire, F., 2014. Extension of the TAMSAT satellite-Based rainfall Monitoring over $\Lambda$ friea and from 1983 to PresentExtension of the TAMSAT satellite-based rainfall monitoring over Africa and from 1983 to present. J. Appl. Meteorol. Climatol. 53, 2805-2822. doi:10.1175/JAMC-D-14-0016.1.

Tierney, J.E., Smerdon, J.E., Anchukaitis, K.J., Seager, R., 2013. Multidecadal variability in East African hydroclimate controlled by the Indian Ocean. Nature 493, 389-392. doi:10.1038/nature11785.

Kevin Trenberth, National Center for Atmospheric Research Staff. The Climate Data Guide: Nino SST Indices (Nino 1+2, 3, 3.4, 4; ONI and TNI). [WWW Document]. URL https://climatedataguide.ucar.edu/ climate-data/nino-sst-indices-nino-12-3-34-4-oni-and-tni, 2019. (accessed 12.2.19).

Vrieling, A., Meroni, M., Mude, A.G., Chantarat, S., Ummenhofer, C.C., de Bie, K., 2016. Early assessment of seasonal forage availability for mitigating the impact of drought on East African pastoralists. Remote Sens. Environ. 174, 44-55. doi:10.1016/j.rse.2015.12.003.

Williams, A.P., Funk, C., 2011. A westward extension of the warm pool leads to a westward extension of the Walker circulation, drying eastern Africa. Clim. Dyn. 37, 2417-2435. doi:10.1007/s00382-0100984-y.

WMO, 2012. Standardized Precipitation Index (User Guide). WMO-No. 1090.

WMO, 2013. The global Climate 2001-2010. a decade of elimate extremesthe global climate 20012010. a decade of climate extremes. In: Summary report (No. 1119).

Wolff, C., Haug, G.H., Timmermann, A., Damsté, J.S.S., Brauer, A., Sigman, D.M., Cane, M.A., Verschuren, D., 2011. Redueed Interannttal Rainfall Variability in East Afriea During the Last Iee AgeReduced Interannual Rainfall Variability in East Africa during the last Ice Age. Science 333, $743-$ 747. doi:10.1126/science.1203724.

WWF, 2006. Climate Change Impacts on East Africa. A Review of the Scientific Literature. World Wide Fund For Nature.

\section{Graphical abstract:}


In the 2000s, the eastern parts of the region are drier than the 1980s and 1990s. On the other hand, the western parts of Ethiopia and Kenya are wetter in the 2000s compare to the 1980s. Regarding temperature, however, the 2000s is the warmest decade compared to the 1980s and 1990s, which is in line with global warming.

alt-text: Unlabelled Image

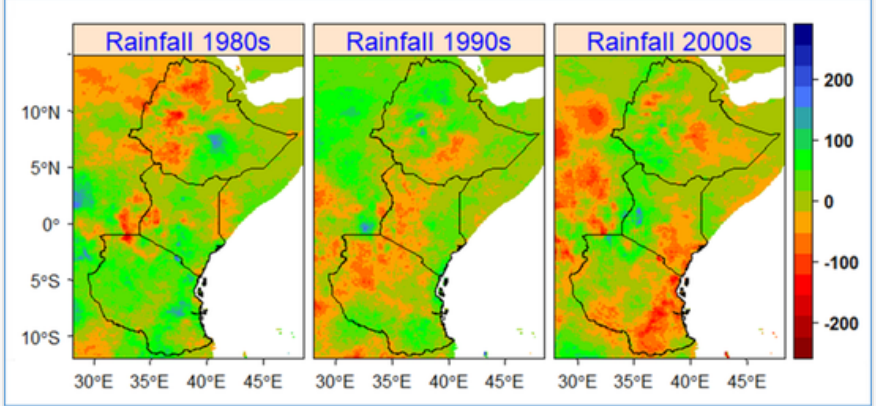

\section{Highlights:}

- High-resolution datasets help detect changes and variability in climate at local-scale.

- Variability in rainfall during the short rain season is linked with Indian Ocean Dipole.

- The 2000s is the warmest and driest decade compared to 1980s and 1990s.

- Droughts are increasing in large parts of the region and it is linked with Nĩno3.4 index.

- High-resolution drought maps allow the development of adaptation measures at a local scale.

\section{Queries and Answers}

Query: Your article is registered as a regular item and is being processed for inclusion in a regular issue of the journal. If this is NOT correct and your article belongs to a Special Issue/Collection please contact s.sankaran@elsevier.com immediately prior to returning your corrections.

Answer: yes the article id a regular iten and doesnt belong to any special issue

Query: Please confirm that given names and surnames have been identified correctly and are presented in the desired order, and please carefully verify the spelling of all authors' names.

Answer: it is correct! 
Query: The author names have been tagged as given names and surnames (surnames are highlighted in teal color).

Please confirm if they have been identified correctly.

Answer: it is correct!

Query: Correctly acknowledging the primary funders and grant IDs of your research is important to ensure compliance with funder policies. We could not find any acknowledgement of funding sources in your text. Is this correct?

Answer: Yes 